\title{
Molecular identification of Ageratum enation virus (AEV) associated with leaf curl disease of tomato (Solanum lycopersicum) in India
}

\author{
P. Swarnalatha - M. Mamatha - M. Manasa • \\ R. P. Singh • M. Krishnareddy
}

Received: 9 January 2013 / Accepted: 8 April 2013 /Published online: 21 May 2013

(C) Australasian Plant Pathology Society Inc. 2013

\begin{abstract}
Leaf samples of tomato plants showing severe leaf curl symptoms were collected from Pantnagar, Uttarakhand state of India. Full-length clones of a monopartite begomovirus were isolated and complete genome sequence was determined. Genome organization of this virus was found to be similar to those of other old world begomoviruses. Neither alphasatellite nor DNA B component was detected. The DNA-A molecule (2753 nt) sequences showed the highest levels of nucleotide sequence identity of 92.9 to $98.7 \%$ with the DNA-A of Ageratum enation virus (AEV) isolates and less identity of 77.1 to $86.3 \%$ with known tomato-infecting begomoviruses from India. The incidence of AEV in protected cultivation was upto $68.5 \%$ noticed.
\end{abstract}

Keywords Ageratum enation virus · Tomato ·

Begomovirus · Molecular identification · India $\cdot$ Polymerase chain reaction $\cdot$ Rolling circle amplification $(\mathrm{RCA})$

The Geminiviridae is the second largest family of plant viruses and is characterized by a circular, single-stranded DNA virus with characteristic quasi-icosahedral particles (geminate, 18$22 \mathrm{~nm}$ diameters) (Böttcher et al. 2004). The viruses in this family are divided across four genera that are distinguished on

P. Swarnalatha $\cdot$ M. Manasa $\cdot$ M. Krishnareddy $(\bowtie)$

Division of Plant Pathology, Indian Institute of Horticultural

Research, Hessaraghatta Lake PO,

Bangalore 560089, India

e-mail: mkreddy@iihr.ernet.in

M. Krishnareddy

e-mail: mkreddy60@gmail.com

M. Mamatha $\cdot$ R. P. Singh

Department of Plant Pathology, GB Pant University of Agriculture

and Technology, Pant, Nagar, Uttarakhand, India the basis of host range, insect vector and genome arrangement (Fauquet et al. 2008). Economically the most important geminiviruses are in the genus Begomovirus. Begomoviruses are transmitted exclusively by the whitefly Bemisia tabaci (Jones 2003). In the Old World the majority of begomoviruses have monopartite genomes, although a small number have bipartite genomes consisting of DNA-A and DNA-B. The DNA-A encodes all factors required for virus replication, overcoming host defenses, insect transmission and control of gene expression, while DNA-B encodes factors required for inter- and intracellular movement in host plants (HanleyBowdoin et al. 1999). The majority of the monopartite begomoviruses instead associate with a newly identified class of single-stranded DNA satellites termed betasatellites (Briddon and Stanley 2006).

Tomato (Solanum lycopersicom) is one of the major vegetable crops grown all over India under diverse climatic conditions. Tomato leaf curl disease (ToLCD) is the most detrimental factor for tomato production all over the world. Tomato leaf curl disease caused by a whitefly-transmitted virus was first reported in 1948 in northern India by Vasudeva and Samraj (1948). Upon infection, viruses associated with the disease produce vein clearing, leaf curling, reduction in leaf lamina, vein enation and stunting in plants. In India, leaf curl disease can be caused by 14 species of viruses belonging to the genus Begomovirus, family Geminiviridae. Here we characterize a virus affecting tomato in Pantnagar and show it to be an isolate of the begomovirus Ageratum enation virus (AEV), the first time a weed infecting begomovirus species has been identified naturally infecting tomato in India. The incidence of leaf curl disease is varied from 27.6 to $68.5 \%$ in five different polyhouses of $1.25 \mathrm{ha}$. Of the randomly collected 51 tomato leaf curl samples, all the samples were positive in PCR amplification using begomovirus specific primers. 
Leaf samples of tomato showing sever leaf curling, vein clearing, vein enation, reduction in leaf lamina and stunted growth symptoms were collected in playhouse grown tomatoes, areas around Pantnagar, the tarai region of Uttarakhand state, India in 2012 (Fig. 1). Samples were used for B.tabaci acquisition and transmission of the putative viruses present to healthy tomato plants grown in glasshouse by using 12 and $24 \mathrm{~h}$ acquisition and inoculation access periods respectively. The plants showing typical leaf curl symptoms were maintained in the insect free glasshouse. Total nucleic acids were extracted from leaf samples of inoculated plants by the modified cetyl trimethyl ammonium bromide (CTAB) method (Venkataravanappa et al. 2012). A partial clone of the begomovirus was obtained by polymerase chain reaction (PCR) amplification with begomovirus group-specific primers (Venkataravanappa et al. 2012). After confirming the begomovirus nature, complete viral genomic DNA was amplified through rolling-circle amplification (RCA) (Haible et al. 2006). RCA product was digested individually with BamHI, EcoRI, HindIII and KpnI. Only BamHI and HindIII gave clear bands of $2.7 \mathrm{~kb}$. Both the bands were selected for cloning. The complete nucleotide sequence of clones from each sample (three clones for each sample were sequenced) were determined by automated DNA sequencer, ABI PRISM

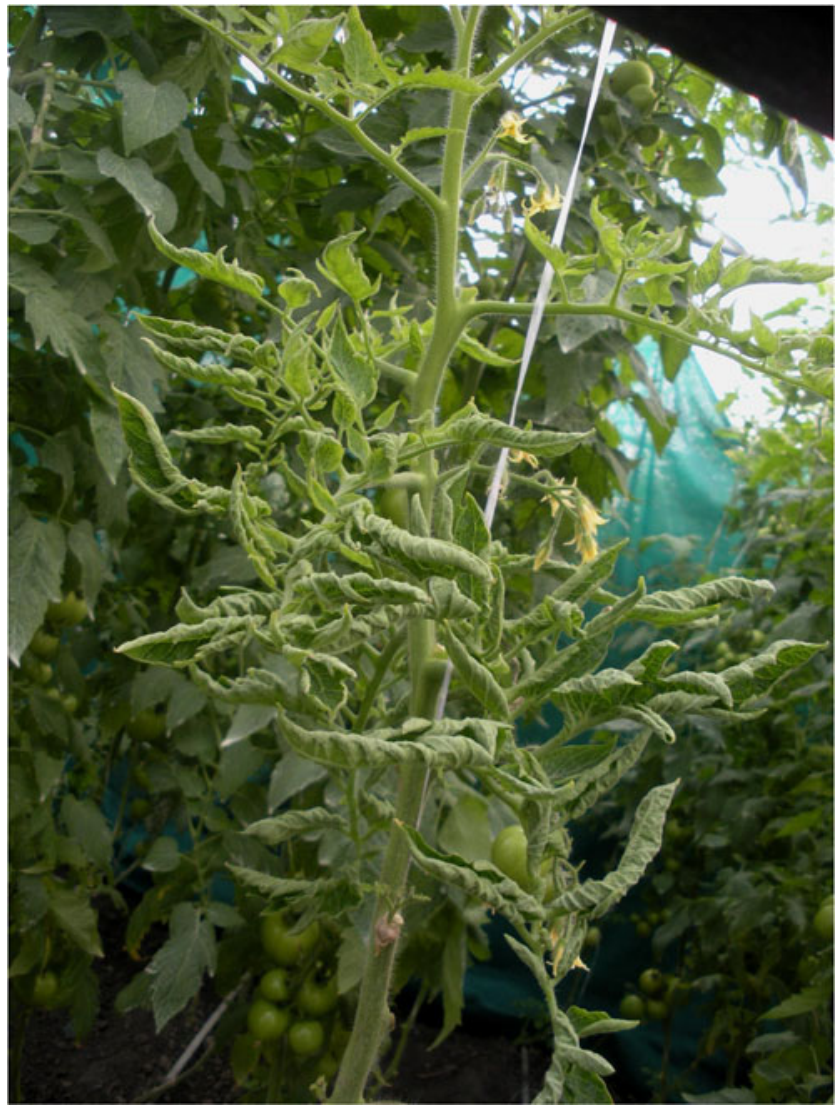

Fig. 1 Severe leaf curling symptom of tomato in which Ageratum enation virus isolated
3730 (Applied Biosystems) from Eurofins Genomics India Pvt. Ltd, Bangalore, India. The sequences obtained were verified for the presence of all Begomovirus specific ORFs (using NCBI ORF finder) and conserved nonanucleotide sequence. The sequence results were analyzed using NCBI (www.ncbi.nlm.nih.gov) blast search, followed by multiple sequence alignments using ClustalX (Thompson et al. 1997) and Bioedit Sequence Alignment Editor (version 5.0.9) (Hall 1999), to determine percentage sequence identity with other species, which showed maximum identity in the blast search. Full-length genome of selected Begomovirus species, phylogenetic trees were generated by MEGA 5.0 software (Tamura et al. 2011), using the neighbor joining method with 1000 bootstrapped replications, to estimate evolutionary distances between all pairs of sequences simultaneously.

The complete nucleotide sequence of the DNA-A component was determined to be 2753 bp in length (acc. No. JX436472). Sequence analysis of the DNA component is predicted to contain six open reading frames (ORFs) with an arrangement typical of the DNA-A components of the Old World begomoviruses, consisting of two ORFs in the virionsense (encoding the coat protein (CP) and V2 and four in the complementary-sense (encoding the replication associated protein (Rep), the transcriptional activator protein (TrAP), the replication enhancer protein [REn] and $\mathrm{C} 4$. The features of this newly derived DNA-A component are summarized in Table 1.

Of the 51 samples analyzed for begomovirus specificity, $12.0 \%$ of samples were infected with Tobacco curly shoot virus and remain $88.0 \%$ were infected with Ageratum enation virus and none of the sample showed any mixed infection. Further primers specific to DNA-B and Alfasatellites did not result any positive amplification from all the samples tested. Multiple alignment and sequence comparison of present isolate with tomato infecting begomoviruses from Indian subcontinent showed 92.9 to $98.7 \%$ with known AEV isolates infecting Crop and weed hosts in India (Table 1). Where as 77.1 to $86.3 \%$ homology with known tomato infecting begomoviruses from Indian subcontinent. Phylogenetic dendrogram, based on alignment of complete DNA-A sequences of the majority of tomato-infecting begomoviruses of Indian sub-continent origin and other begomoviruses shows that AEV.tomato does not cluster with any other tomato-infecting begomovirus species originating from India rather it is placed on a separate Claude with AEV infecting begomovirus species (Fig. 2).

In India, diseases caused by whitefly-transmitted begomoviruses are on increase, affecting the cultivation and economic yield of vegetables, including tomato. Increased overlapping cultivation of tomato and closely related solanaceous crops has resulted in an expanded host range of existing begomoviruses and has led to the emergence of new strains and recombinants. This is especially true for 
Table 1 Pairwise comparisons of percent nucleotide identities between the genomic components and amino acid sequence identities of encoded genes of AEV infecting tomato with selected begomoviruses from NCBI the database

\begin{tabular}{|c|c|c|c|c|c|c|c|c|}
\hline \multirow[t]{2}{*}{ Begomoviruses } & \multicolumn{2}{|c|}{$\begin{array}{l}\% \text { nt identity of } \\
\text { AEV.Tomato isolate }\end{array}$} & \multicolumn{6}{|c|}{$\%$ amino acid identity of AEV.Tomato isolate } \\
\hline & Full genome & IR & AV1 & AV2 & $\mathrm{AC} 1$ & $\mathrm{AC} 2$ & $\mathrm{AC} 3$ & $\mathrm{AC} 4$ \\
\hline JX436473|AEV.Fenugreek.BG199 & 98.7 & 98.9 & 99.6 & 97.4 & 97.5 & 95.5 & 97.7 & 98.8 \\
\hline FN794201|AEV.Palampur.Crassocephalum crepidioides.UwuA & 98.4 & 98.6 & 100 & 97.4 & 98.6 & 94.7 & 97.7 & 98.8 \\
\hline FN543099|AEV.HP.Zinnia sp. & 98.2 & 97.9 & 100 & 974 & 98.0 & 94.7 & 97.7 & 100 \\
\hline HE861940|AEV.Palampur.Glycine max & 98.1 & 70.8 & 99.6 & 97.4 & 98.3 & 97.0 & 97.7 & 95.2 \\
\hline JF728866|AEV.Mohali.Ageratum conyzoides10 & 97.8 & 72.5 & 100 & 97.4 & 98.0 & 91.0 & 97.0 & 98.8 \\
\hline JF682242|AEV.Lucknow.Amaranthus hypochondriacus & 97.5 & 97.2 & 99.2 & 97.4 & 97.5 & 94.7 & 91.0 & 96.4 \\
\hline JF728865|AEV.Mohali.Daucus carota9 & 96.9 & 69.4 & 97.6 & 95.7 & 96.6 & 95.5 & 98.5 & 89.4 \\
\hline JQ911765|AEV.Lucknow.Papaver somniferum & 96.5 & 73.2 & 96.4 & 95.7 & 97.5 & 97.0 & 97.0 & 97.6 \\
\hline AM261836|AEV.SonAL8.Sonchus oleraceus & 94.1 & 38.1 & 97.6 & 97.4 & 93.9 & 90.2 & 97.7 & 84.7 \\
\hline FJ177031|AEV.Lucknow.Cleome gynandra & 93.5 & 25.0 & 100 & 95.7 & 92.7 & 94.7 & 91.0 & 85.8 \\
\hline GQ268327|AEV.Gorakhpur.Trichosanthes dioica & 93.4 & 25.0 & 99.6 & 96.6 & 93.3 & 96.2 & 91.7 & 84.7 \\
\hline AM701770|AEV.Faisalabad.Turnip & 92.9 & 20.1 & 99.6 & 94.0 & 93.0 & 94.7 & 93.2 & 83.5 \\
\hline AJ437618|AEV.Nepal.Ageratum conyzoides & 92.9 & 24.6 & 99.2 & 94.9 & 93.9 & 92.5 & 91.0 & 84.7 \\
\hline AF188481|ToLCBdV.Bangladesh & 86.3 & 29.0 & 99.6 & 98.3 & 83.3 & 84.3 & 88.0 & 48.4 \\
\hline GU732204|ToLCPkV.[IN:Bih] & 86.0 & 27.6 & 98.0 & 92.3 & 63.0 & 88.0 & 86.5 & 61.8 \\
\hline JN387045|TbCSV.To-Ag-1 & 85.8 & 25.5 & 97.2 & 94.0 & 82.8 & 87.3 & 92.5 & 44.3 \\
\hline GQ994095|ToLCRaV & 85.7 & 25.9 & 98.8 & 94.0 & 81.4 & 88.0 & 91.0 & 42.2 \\
\hline EU910141|ToLCKeV.K3 & 84.0 & 26.6 & 96.0 & 90.6 & 80.0 & 90.2 & 87.3 & 81.0 \\
\hline U38239|ToLCKV.Bangalore II & 83.6 & 34.3 & 96.8 & 95.7 & 81.4 & 86.5 & 88.0 & 44.3 \\
\hline JQ654460|ToLCJoV.HJP3 & 82.9 & 27.6 & 98.0 & 42.0 & 83.3 & 82.8 & 76.8 & 10.1 \\
\hline AY190290|ToLCGV.[Varanasi] & 79.9 & 25.0 & 80.8 & 83.8 & 81.1 & 84.3 & 82.0 & 13.2 \\
\hline AY754814|ToLCPuV.[India:Pune:2005] & 78.4 & 29.8 & 91.0 & 70.3 & 79.2 & 82.8 & 79.1 & 49.4 \\
\hline JN135234|ToLCLV & 78.1 & 26.0 & 96.0 & 88.9 & 73.4 & 74.6 & 73.1 & 51.7 \\
\hline DQ339117|ToLCRV.[India:Rajasthan:2005] & 77.7 & 24.2 & 97.6 & 94.0 & 75.9 & 57.4 & 44.0 & 44.7 \\
\hline EU862323|ToLCPV. & 77.7 & 26.3 & 16.7 & 66.1 & 81.4 & 21.4 & 68.6 & 65.0 \\
\hline AF165098|ToLCBV.Ban4 & 77.1 & 28.4 & 87.5 & 70.3 & 78.1 & 81.3 & 82.8 & 44.3 \\
\hline
\end{tabular}

tomato, which is grown in diverse agroclimatic zones throughout the year, thus perpetuating the virus inoculum and vector population (Varma et al. 2011). In this context, considerable progress has been made in characterizing tomato begomoviruses in southern, western and northern India. Although incidence of tomato leaf curl disease (ToLCD) in India was first reported from northern region (Vasudeva and Samraj 1948), this disease is now widely spread in almost all tomato growing regions of country. A total of 14 tomato infecting begomovirus species are known to be associated with ToLCD in India (Brown et al. 2012; Fauquet et al. 2008). Tomato leaf curl Bangalore virus (ToLCBV), Tomato leaf curl Karnataka virus (ToLCKV), and Tomato leaf curl Kerala virus (ToLCKeV) from southern India (Chatchawankanphanich and Maxwell 2002; Kirthi et al. 2002; Muniyappa et al. 2000). Whereas Papaya leaf curl virus (PaLCV), Tomato leaf curl New Delhi virus (ToLCNDV), Tomato leaf curl Gujarat virus (ToLCGV),
Tomato leaf curl Palampur virus (ToLCPaV), Tomato leaf curl Pune virus (ToLCPuV), Tomato leaf curl and Rajasthan virus (ToLCRV) from northern India (Padidam et al. 1995; Chakraborty et al. 2003; Kumar et al. 2008; Srivastava et al. 1993), Cotton leaf curl Burewala virus (CLCuBV), Tomato leaf curl Ranchi virus (ToLCRnV), Tomato leaf curl Patna virus (ToLCPV) and Tomato leaf curl Joydebpur virus (ToLCJV) have been reported from Eastern India (Kumari et al. 2009, 2010, 2011; Tiwari et al. 2012). With an increasing number of samples analyzed from different locations, it is now evident that both monopartite and bipartite begomoviruses are distributed throughout India, and the earlier opinion (Chowda Reddy et al. 2005) that the distribution of bipartite virus occurs only in northern region is no longer valid. This is the first report of the occurrence of AEV on tomato in India, although it is known to occur on several weed 
Fig. 2 Phylogenetic tree of complete nucleotide sequences of the DNA-A of the Ageratum enation virus $(\mathrm{AEV})$ isolate originating from Pantnagar with selected other begomoviruses available in the databases. The $\mathrm{AEV}$ isolate originating from pantnagar is highlighted. The number at the nodes indicate the bootstrap confidence values (1000 replicates). For each isolate the database accession numbers are given

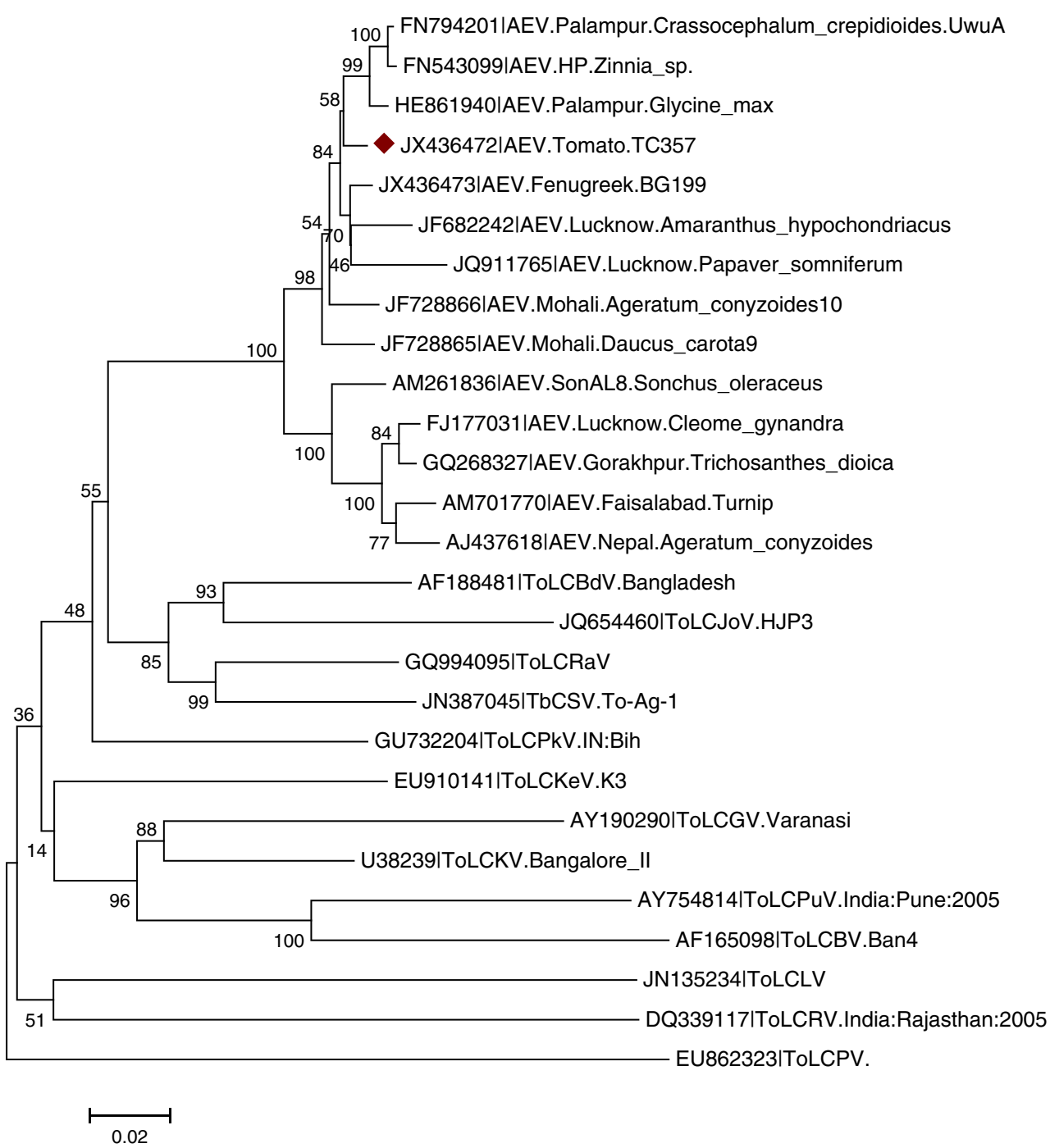

hosts. This has significance in the epidemics of tomato leaf curl disease from a weed host spreading to cultivated plants being more than $50 \%$ incidence in protected cultivation.

\section{References}

Böttcher B, Unseld S, Ceulemans H, Russell RB, Jeske H (2004) Geminate structures of African cassava mosaic virus. J Virol 78:6758 6765

Briddon RW, Stanley J (2006) Sub-viral agents associated with plant infecting single-stranded DNA viruses. Virology 344:198-210

Brown JK, Fauquet CM, Briddon RW, Zerbini M, Moriones E, NavasCastillo J (2012) Virus taxonomy: classification and nomenclature of viruses: Ninth Report of the International Committee on Taxonomy of Viruses. In: King AMQ, Adams MJ, Carstens EB, Lefkowitz EJ (eds) Part II-single stranded DNA viruses. Elsevier, pp 359-373
Chakraborty S, Pandey PK, Banerjee MK, Kalloo G, Fauquet CM (2003) Tomato leaf curl Gujarat virus, a new Begomovirus species causing a severe leaf curl disease of tomato in Varanasi. India Phytopathol 93:1485-1495

Chatchawankanphanich O, Maxwell DP (2002) Tomato leaf curl Karnataka virus from Bangalore, India, appears to be a recombinant begomovirus. Phytopathology 92:637-645

Chowda Reddy RV, Colvin J, Muniyappa V, Seal S (2005) Diversity and distribution of begomoviruses infecting tomato in India. Arch Virol 150:845-867

Fauquet CM, Briddon RW, Brown JK, Moriones E, Stanley J, Zerbini M, Zhou X (2008) Geminivirus strain demarcation and nomenclature. Arch Virol 153:783-821

Haible D, Koher S, Jeske H (2006) Rolling circle amplification revolutionizes diagnosis and genomics of geminivirous. J Virol Methods 135:9-16

Hall TA (1999) BioEdit: a user-friendly biological sequence alignment editor and analysis program for Windows 95/98/NT. Nucleic Acids Symp Ser 41:95-98

Hanley-Bowdoin L, Settlage SB, Orozco BM, Nagar S, Robertson D (1999) Geminiviruses: models for plant DNA replication, transcription, and cell cycle regulation. Crit Rev Plant Sci 18:71-106 
Jones DR (2003) Plant viruses transmitted by whiteflies. Eur J Plant Pathol 109:195-219

Kirthi N, Maiya SP, Murthy MRN, Savithri HS (2002) Evidence of recombination among the tomato leaf curl strains/species from Bangalore, India. Arch Virol 147:255-272

Kumar Y, Hallan V, Zaidi AA (2008) Molecular characterization of a distinct bipartite begomovirus species infecting tomato in India. Virus Genes 38:193-200

Kumari P, Chattopadhyay B, Singh AK, Chakraborty S (2009) A new begomovirus species causing tomato leaf curl disease in Patna. India Plant Dis 93:545

Kumari P, Singh AK, Sharma VK, Chattopadhyay B, Chakraborty S (2010) Molecular characterization of a new species of Begomovirus and beta satellite causing leaf curl disease of tomato in India. Virus Res 152:19-29

Kumari P, Singh AK, Chattopadhyay B, Chakraborty S (2011) A new begomovirus species and betasatellite causing severe tomato leaf curl disease in Ranchi, India. New Dis Rep 23:11. doi:10.5197/ j.2044-0588.2011.023.011

Muniyappa V, Venkatesh HM, Ramappa HK, Kulkarni RS, Zeidan M, Tarba CY, Ghanim M, Czosnek H (2000) Tomato leaf curl virus from Bangalore (ToLCV-Ban4): sequence comparison with Indian ToLCV isolates, detection in plants and insects, and vector relationships. Arch Virol 145:1583-1598

Padidam M, Beachy RN, Fauquet CM (1995) Tomato leaf curl geminivirus from India has a bipartite genome and coat protein is not essential for infectivity. J Gen Virol 76:25-35
Srivastava KM, Hallan V, Raizada RK, Chandra G, Singh BP, Sane PV (1993) Molecular cloning of Indian tomato leaf curl virus genome following a simple method of concentrating the supercoiled replicative form of viral DNA. J Virol Methods 51:297-304

Tamura K, Peterson D, Peterson N, Stecher G, Nei M (2011) MEGA5: molecular evolutionary genetics analysis using maximum likelihood, evolutionary distance, and maximum parsimony methods. Mol Biol Evol 28:2731-2739

Thompson JD, Gibson TJ, Plewniak F, Jeanmougin F, Higgins DG (1997) The ClustalXwindows interface; flexible strategies for multiple sequence alignment aided by quality analysis tools. Nucleic Acids Res 25:4876-4882

Tiwari N, Singh VB, Sharma PK, Malathi VG (2012) Tomato leaf curl Joydebpur virus: a monopartite begomovirus causing severe leaf curl in tomato in West Bengal. Arch Virol

Varma A, Mandal B, Singh MK (2011) Global emergence and spread of whitefly (Bemasia tabaci) transmitted Geminiviruses. In: Thompson WMO (ed) The whitefly Bemasia tabaci (Homoptera; Aleyrodidae) interaction with geminiviruses infected host plants. Springer, Netherlands, p 205-292

Vasudeva RS, Samraj J (1948) A leaf curl disease of tomato. Phytopathology 38:364-369

Venkataravanappa V, Lakshminarayana Reddy CN, Jalali S, Krishna Reddy M (2012) Molecular characterization of distinct bipartite begomovirus infecting bhendi (Abelmoschus esculentus L.) in India. Virus Genes 44:522-535 